\title{
Identification of Potential Groundwater Recharge Sites in a Semi-arid Region of Pakistan Using Saaty's Analytical Hierarchical Process (AHP)
}

\begin{abstract}
Groundwater is a precious source of fresh water and a major component of the entire water supply. Both water quality and quantity could be satisfied by evaluating the groundwater potential sites (GWPS). This paper analyzes the groundwater potentials in a semi-arid region of Khyber Pakhtunkhwa, Pakistan. It describes a standard methodology to identify and map GWPS using integrated Geographical Information System (GIS) and remote sensing (RS) methods. Eight parameters including elevation, slope, drainage density, lineaments density, soil, geology, land use/land cover and rainfall were integrated to explore areas with groundwater holding capability. GWPS were delineated through subjective weights assigned after coupling various thematic layers using Saaty's Analytical Hierarchical Process (AHP). The modelled GWPS were cross-checked with tube wells data. The result indicates that the central part of the study area has good potential for groundwater reserves/exploitation, where the factors i.e. moderate to high drainage density, sedimentary sequence of alluvial plain, low elevation etc. discern the central portion of the study area as a suitable site for groundwater. This study suggests that the applied method proves to be very significant and reliable tool for timely assessment of quality assured evaluation of groundwater resources. This study could be a systematic guide for future investigations for water related explorations, especially in semi-arid environments.
\end{abstract}

Keywords: Saaty's Analytical Hierarchical Process (AHP), weighted overlay analysis, semi-arid region, groundwater potential sites, GIS and remote sensing

Received: 9 August 2021; accepted: 11 October 2021

(C) 2022 Authors. This is an open access publication, which can be used, distributed and reproduced in any medium according to the Creative Commons CC-BY 4.0 License.

1 GIS and Space Application in Geosciences Lab (G-SAG), National Centre for GIS and Space

Applications (NCGSA); University of Peshawar, National Centre of Excellence in Geology, Peshawar, Pakistan, email: msuliman07@gmail.com (corresponding author),

(D) https://orcid.org/0000-0003-3476-7384

2 University of Peshawar, Department of Geography, Peshawar, Pakistan, email: samigeo78@uop.edu.pk, (1) https://orcid.org/0000-0003-4993-6443

3 GIS and Space Application in Geosciences Lab (G-SAG), National Centre for GIS and Space Applications (NCGSA); University of Peshawar, National Centre of Excellence in Geology, Peshawar, Pakistan, email: aliumarzai@uop.edu.pk, (1) https://orcid.org/0000-0002-2866-1623 


\section{Introduction}

Water is a sustainable natural resource for drinking and irrigation, especially in those regions with prevailing semi-arid climatic conditions. It is the most abundant element necessary for life, found in different forms i.e. glaciers, streams, rivers, lacks, canals, springs and waterfalls on the Earth's surface [1, 2]. It plays a significant role in human life, ecological settings and economic growth of human societies [1]. At a global scale, water demand has increased over the years, therefore, its proper assessment with significant utilization has become important [3, 4]. Groundwater assets, constitute more than $70 \%$ of the water supply in arid environments, are now often depleted due to over-exploitation, lack of infiltration, land use changes and population growth $[5,6]$.

Due to environmental degradation in semi-arid regions, groundwater could be used as a significant key to predict a dry season that will result in reduced surface water availability [7, 8]. Groundwater resources need to be monitored properly in order to cope with groundwater depletion crises and the impacts of climate change on water resources [4,9]. Excessive extraction from the aquifer leads to the depletion of the sub-surface water table. Also, gradually depleting water quality, decreasing waterflow in streams/lakes and land subsidence are critical issues associated with water-scarce regimes [5]. Therefore, timely and precise monitoring of groundwater resources could assist the decision-making process and sustainable groundwater plans with better accuracy [9-11]. Compared to conventional approaches (i.e. hydrogeological examinations, drilling processes and field surveys), modern GIS and RS techniques could be used as handy tool for mapping potential groundwater zones using multiple geo-environmental parameters [2, 3, 12].

Pakistan is facing water scarcity issues, despite having plenty of water resources in the form of glaciers, rivers and streams. The amount of water available in 1947 was 5,000 $\mathrm{m}^{3}$ for each Pakistani, which has now reduced to 1,000 $\mathrm{m}^{3}$ due to uncontrolled population growth and over exploitation [13, 14]. According to the United Nations' World Water Development (WWD) Report, the total actual renewable water resources in Pakistan decreased from 2,961 $\mathrm{m}^{3}$ in 2000 to $1,420 \mathrm{~m}^{3}$ in 2005 [15], while this number will further reduce to $800 \mathrm{~m}^{3}$ by 2025 [7]. Pakistan has sustained water potential challenges due to weak and outdated infrastructure, which wastes even more water, while little is stored to lakes/surface dams and sub-surface reservoirs [15]. At the same time, the country has a widespread agriculture sector, which uses various methods for irrigation (i.e. canal/stream irrigation, lift irrigation, barrages and small dams) to retain extra water for agricultural supply $[7,16,17]$.

Sustainable exploitation of groundwater resources in the northwest of Pakistan (especially the southern parts of the Khyber Pakhtunkhwa Province) is one of the optimal necessities for irrigation and drinking purposes [14, 17]. The conventional techniques and over extraction from aquifers promulgate problems of permeability, 
salinity and toxicity. A high concentration of salt in the soil may block the soil pores, which reduces land fertility and decreases water infiltration to sub-surface aquifers [18]. The climate of the study area is sub-tropical to semi-arid, which necessitates sustainable water for their domestic use and agricultural pursuits [14]. Therefore, the utilization of GIS and state of art remote sensing techniques offer systematic, time and cost-effective procedures to produce a reliable methodology to identify groundwater potential sites (GWPS) on a larger scale [19, 20].

In recent years, many geoscientists have widely used GIS and remote sensing techniques to better monitor the surface/sub-surface dynamics of groundwater resources worldwide. Assessing GWPS, geospatial data provide a perfect platform (cost-effective and time-effective opportunities) for sustainable groundwater resource planning and its proper management [1, 21]. The decision-making Analytical Hierarchy Process (AHP) approach has used spatial data more efficiently and reliably in groundwater management systems [4, 11, 22, 23]. Previously, the GIS-based AHP had been widely used by researchers for decision support system i.e., Aneesh and Deka [5] proposed a standard methodology using AHP technique. They integrated various thematic layers for the identification of GWPS in Bengaluru urban district, Karnataka, India. Singh et al. [3] used a systematic AHP technique for the demarcation of groundwater potential recharge zonation for the district of Uttar Pradesh, India. Similarly, Yeh et al. [21] used AHP techniques by integrating five contributing parameters for groundwater potentials such as lithology, land cover/land use, lineaments density, drainage density and slope. The outcome from these integrated parameters contributed to the suitable GWPS of the Chih-Pen Creek basin in eastern Taiwan. The resultant GWPS map will be useful for the effective identification of suitable locations for the extraction of freshwater, especially in semi-arid environments [1, 10, 12, 19].

The present study aims to highlight an important mechanism and some of the crucial problems critical for the timely assessment of groundwater identification. This study applied an integrated approach for various parameters i.e. drainage density, elevation, slope, rainfall, lineament density, soil, geology and land use/land cover (LU/LC) and multi-source remotely sensed data using AHP model techniques in a GIS environment. GIS, remote sensing and AHP are malleable in terms of handling and assigning ranks to each layer, corresponding to AHP approaches. In this regard, the main objectives of this study were to:

- investigate and map the GWPS in the study area,

- delineate GWPS by integrating these various thematic layers based on AHP approaches,

- cross-validate the derived GWPS map with tube well data.

The purpose of delineating the GWPS in the study area was to develop a prospective guide map for groundwater exploration/exploitation to ensure the appropriate utilization and sustainable management and development of groundwater resources. 


\section{The Hydrogeology and Hydrological Setting of the Study Area}

The study area, Lakki Marwat, is one of the administrative district of Khyber Pakhtunkhwa province in the northwest of Pakistan covering an area of 3,164 $\mathrm{km}^{2}$. It lies between the latitudes of $32^{\circ} 15^{\prime} 48.10^{\prime \prime}$ to $32^{\circ} 52^{\prime} 18.05^{\prime \prime} \mathrm{N}$ and longitudes of $70^{\circ} 24^{\prime} 11.3^{\prime \prime}$ to $71^{\circ} 14^{\prime} 59.15^{\prime \prime} \mathrm{E}$ (Fig. 1). The study area is located in the southern part of the Bannu basin, with an annual rainfall of about $268.7 \mathrm{~mm}$. It is surrounded by the up-lift boundaries of the Marwat/Khisor, Bhittani and Waziristan-Sulaiman ranges $[14,18]$. The altitude of the study area ranges from $1,943 \mathrm{~m}$ in the Bhittani range to $1,376 \mathrm{~m}$ at the southwestern heights of the Marwat/Khisor range. The sedimentological description of the study area is shown in Figure 2, and is mainly characterized in three broad categories including: alluvial fan, flood plain, and basin-fill sediments [18]. The alluvial fan is composed of coarse-grained (i.e. gravels and boulders) to very fine (such as clays, silt and sandstone) sediments. The flood plain succession consists of silt and sand, with some clay in various proportions. The basin fill are sandy deposits widely found in the northern parts of the Marwat range, mainly transported by erosion [14, 17].
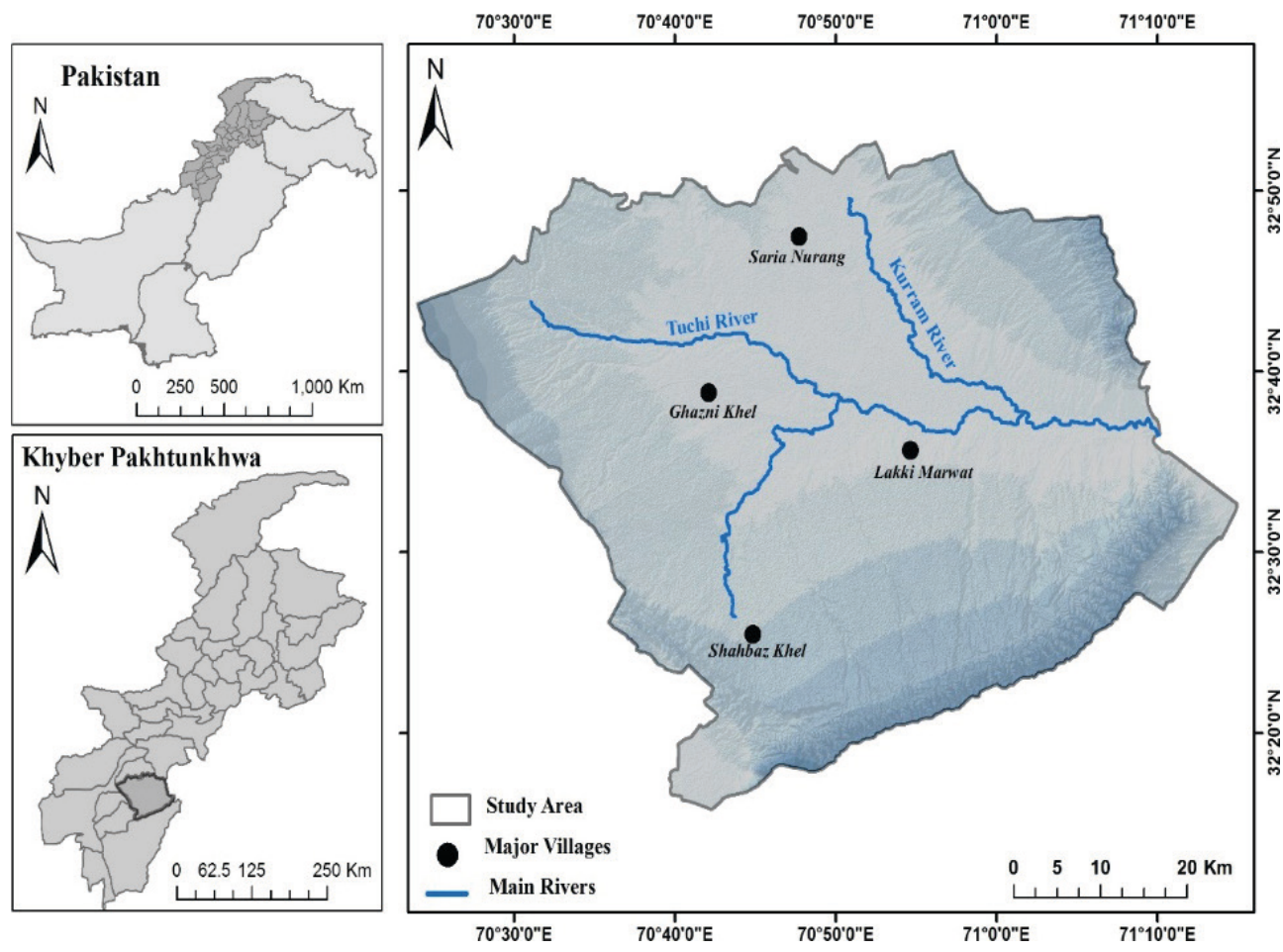

Fig. 1. Location map of the study area 


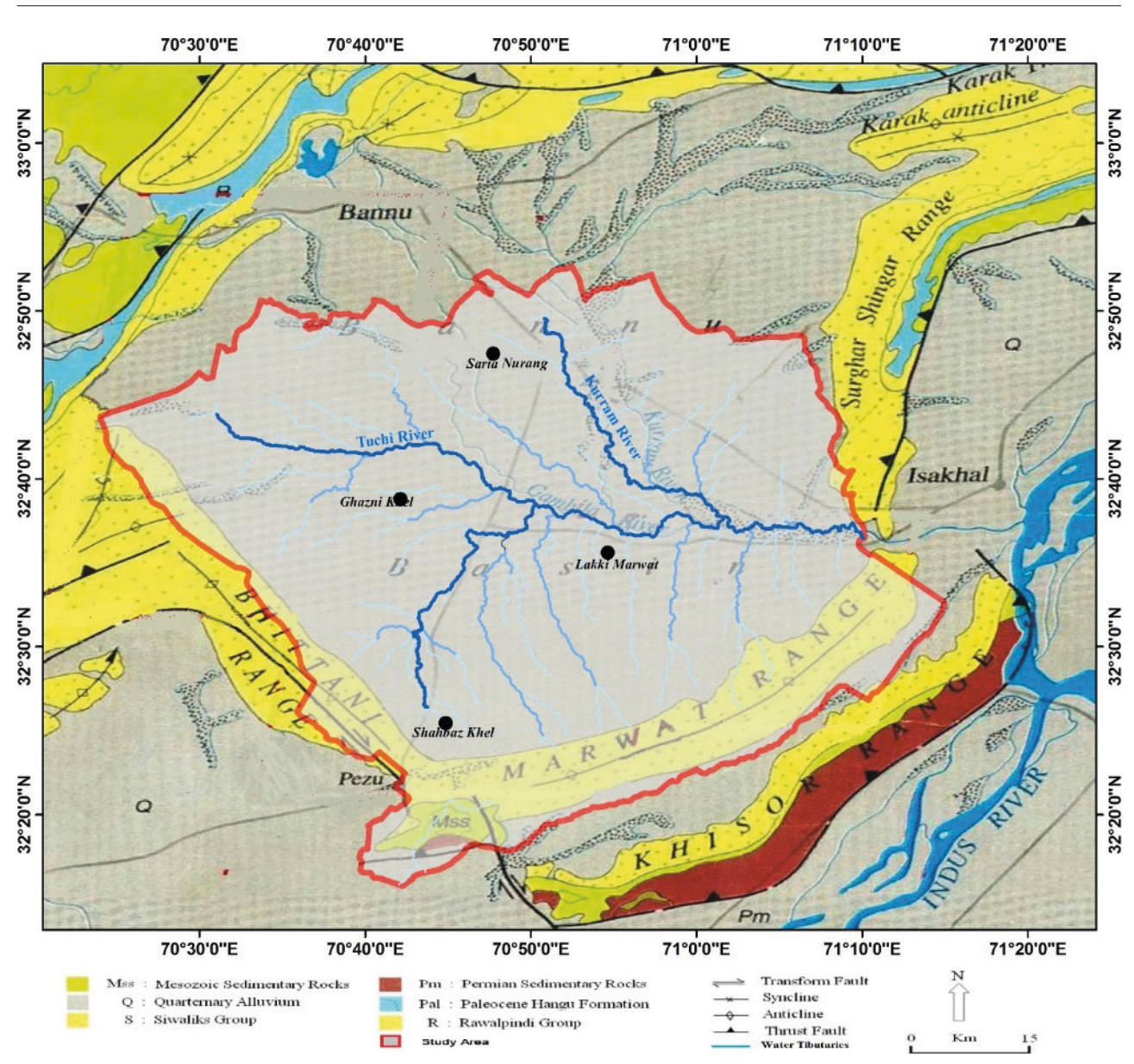

Fig. 2. Hydrogeological map of the study area

Source: modified after [14]

The study area lies in the sub-tropical region of the globe, where the weather is predominantly sunny and dry, with occasional gales and dust storms leading to semi-arid conditions, having all the characteristics of a desert due to the sandbanks, mild winters and hot summers [18]. Most of the streams flow from the surrounding hills to the central part of the basin. In the study area, the Kurram River is the main stream passing through the northwest of the district and joins the mighty the Indus River (Fig. 2) at the southern part of the basin [14, 16]. The second most important tributary of the Kurram River is the Gambila/Tuchi River, which enters the district at the southwest of Bannu, providing an optimal source for Baran Dams (rainfed) and land irrigation. Apart from the main rivers (Kurram and Gambila), several other ephemeral streams which also carry the occasional rainfall water as surface runoff towards the Kurram River and the Gambila River (Fig. 2). The groundwater is the 
major source of water for drinking and irrigation, but accessible in limited pockets, however, groundwater is still far better as compared to surface water which is very rare in the region $[14,16]$. This study aims to map potential sites for groundwater resources, being a vital source for irrigation and drinking, and hence, such a study might be useful for socio-economic development and the effective management of groundwater resources, especially in water scarce regions.

\subsection{State of Art of Groundwater Recharges Evaluation}

The recent development of GIS integrated techniques on multi-spectral remote sensing data has been extensively used for the systematic assessment of GWPS. Therefore, several techniques have been employed by researchers to investigate potential recharge sites worldwide, including logistic regression model (LRM) techniques [24], frequency ratio models [25], empirical algorithm models [19], decision tree model [26] and artificial neural network [20]. For the current study, the GIS-based AHP technique was employed to integrate several contributing parameters (RS-based and in situ) for quantifying groundwater potential based on assigning appropriate weights, ranks with experts guidelines [5, 11, 23]. The Saaty's AHP [27] is a structured technique based on assigning weightages according to the relative significance of the decision criteria, and has been applied in the water resource management and engineering studies [11, 22, 23].

\section{Input Data and Methods}

In this study, multi-spectral remote sensing datasets i.e. Landsat- 8 and Shuttle Radar Topography Mission (SRTM) were used to map the GWPS of the study area. Landsat-8 satellite imagery was freely downloaded from online resources (https:// glovis.usgs.gov/). The satellite tracks the earth in a sun-synchronous orbit at an altitude of $705 \mathrm{~km}$, providing multi-spectral imagery in eleven different spectral regions (bands) with a 16 day repeat cycle. Of these eleven bands, eight i.e. Coastal Aerosol $(0.43-0.45 \mu \mathrm{m})$, Blue $(0.450-0.51 \mu \mathrm{m})$, Green $(0.53-0.59 \mu \mathrm{m})$, Red $(0.64-0.67 \mu \mathrm{m})$, NIR $(0.85-0.88 \mu \mathrm{m})$, SWIR $1(1.57-1.65 \mu \mathrm{m})$, SWIR $2(2.11-2.29 \mu \mathrm{m})$ and Cirrus $(1.36-1.38 \mu \mathrm{m})$ have a ground resolution of $30 \mathrm{~m}$. One band is the panchromatic band with spectral region $0.50-0.68 \mu \mathrm{m}$ and a finer resolution of $15 \mathrm{~m}$, while two bands are acquired in thermal infra-red region, i.e. TIR $1(10.6-11.19 \mu \mathrm{m})$, and TIR $2(11.5-12.51 \mu \mathrm{m})$, with a spatial resolution of $100 \mathrm{~m}$.

The SRTM data was downloaded free of charge from online resources (https:// earthexplorer.usgs.gov/). The reported worldwide vertical accuracy (minimum) of SRTM data is $16 \mathrm{~m}$ with RMSE (Root Mean Square Error) of $9.73 \mathrm{~m}$ (90\% confidence) [28]. The vertical accuracy is associated with variations in slope and altitude, i.e. an increase in slope and altitude reduces accuracy. In this study, eight integrated parameters for groundwater assessment were considered. 
Land use/land cover map of the study area was prepared from Landsat-8 imagery, drainage density, slope and elevation integrated maps were derived from SRTM data, PCI Geomatica software was used for the extraction of lineaments from Landsat-8 panchromatic reflected bands. Soil data was collected from the Soil Survey of Pakistan, from its regional office in Peshawar, while geology data was taken from the National Centre of Excellence in Geology (NCEG), University of Peshawar. The annual rainfall data was taken from the Pakistan Metrological Department, specifically the regional office in Peshawar. The existing tube wells data was taken from the Geo Log International Organization (GLIO). Once the database for all eight parameters was created, Saaty's AHP was applied to rank the weightage of each parameter based on the optimal groundwater potential characteristics (Tab. 1).

Table 1. Rating Scale of Saaty's AHP

\begin{tabular}{|c|c|c|c|c|c|c|c|c||}
\hline $1 / 9$ & $1 / 7$ & $1 / 5$ & $1 / 3$ & 1 & 3 & 5 & 7 & 9 \\
\hline \hline Extremely & $\begin{array}{c}\text { Very } \\
\text { strongly }\end{array}$ & Strongly & moderate & Equal & Moderate & Strongly & $\begin{array}{c}\text { Very } \\
\text { strongly }\end{array}$ & Extremely \\
\hline \multicolumn{10}{|c|}{ Equal More important } \\
\hline
\end{tabular}

Source: [27]

Finally, the spatial distribution and water table of existing tub wells in the study area were used for the verification of the final modeled result. The detailed analytical procedure for this study is given in Figure 3.

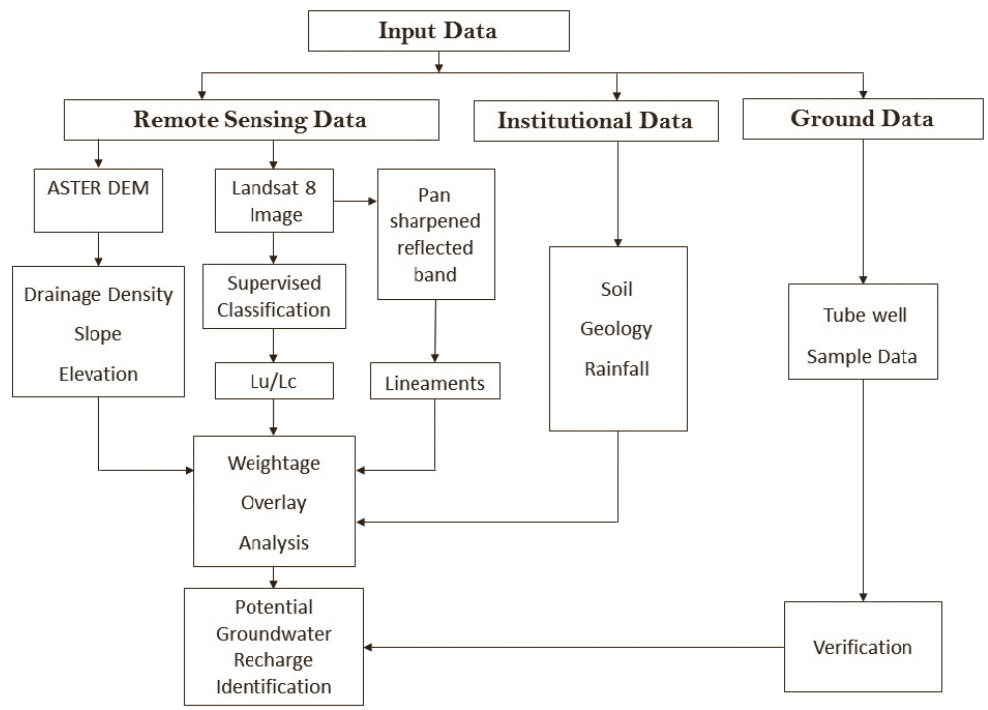

Fig. 3. Flow chart showing the adapted methodology for this study 


\subsection{Determination of Rank and Weights Using Saaty's AHP}

Saaty's AHP process is a set of structured decision support systems [27]. It is a powerful tool for decision-makers to structure their problems in different projects or providing expert knowledge to stakeholders to make good decisions [5, 11]. The Saaty's AHP assessment is best suited in a problem having different parameters that influencing the final outcome. It produces a weightage for each evaluating parameter as per judgment measurements $[5,11]$. Higher the importance of a parameter, higher will be its relative influence, leads to a high weightage $[1,3,12,21]$. The relative influence for every single parameter is determined by Saaty's scale ranging from 1 to 9 [27]. The value 9 shows higher importance while 1/9 shows the least important, where 1 shows the equal weight of a parameter or a class (Tab. 1). Saaty's scale helps to structure the evaluating criteria in a hierarchical order with their relative significance and scale of rank. For the assessment of groundwater mapping, it is necessary to assign appropriate weightage and ranks to different thematic layers to control the potential groundwater in an area. In this study, various literatures have been studied to obtain an adequate idea about each factor influencing the GWPS under distinct environments before assigning ranks and weights. Based on the weightage criteria of individual parameters, the study has been classified as shown in Table 2 .

Table 2. Assigned weightage according to Saaty's AHP

\begin{tabular}{|c|c|c|c|c|c|c|c|}
\hline $\begin{array}{l}\text { Serial } \\
\text { No. }\end{array}$ & $\begin{array}{l}\text { Influencing } \\
\text { factor }\end{array}$ & $\begin{array}{l}\text { Class } \\
\text { interval }\end{array}$ & $\begin{array}{l}\text { Groundwater } \\
\text { availability }\end{array}$ & $\begin{array}{l}\text { Saaty's } \\
\text { scale } \\
\text { [fraction] }\end{array}$ & $\begin{array}{l}\text { Saaty's } \\
\text { scale } \\
\text { [decimal] }\end{array}$ & $\begin{array}{c}\% \text { weight }=(\text { Saaty's } \\
\text { scale/sum }) 100\end{array}$ & $\begin{array}{l}\text { Relative } \\
\text { weight }\end{array}$ \\
\hline \multirow{3}{*}{1} & \multirow{3}{*}{$\begin{array}{c}\text { Drainage } \\
\text { density } \\
{\left[\mathrm{km}^{2}\right]}\end{array}$} & $0-0.6$ & high & 1 & 1 & 65.17 & 65 \\
\hline & & $0.6-1.8$ & moderate & $1 / 3$ & 0.33 & 21.56 & 21 \\
\hline & & $1.8-3.2$ & low & $1 / 5$ & 0.2 & 13.07 & 13 \\
\hline \multicolumn{8}{|c|}{ Sum $=1.53$} \\
\hline \multirow{5}{*}{2} & \multirow{5}{*}{$\begin{array}{l}\text { Elevation } \\
{[\mathrm{m}]}\end{array}$} & $200-300$ & very high & 1 & 1 & 56.17 & 56 \\
\hline & & $300-400$ & high & $1 / 3$ & 0.33 & 16.85 & 17 \\
\hline & & $400-500$ & moderate & $1 / 5$ & 0.2 & 11.23 & 11 \\
\hline & & $500-600$ & low & $1 / 7$ & 0.14 & 7.86 & 8 \\
\hline & & $>600$ & very low & $1 / 9$ & 0.11 & 6.17 & 6 \\
\hline & & & & $\mathrm{m}=1.78$ & & & \\
\hline
\end{tabular}


Table 2. cont

\begin{tabular}{|c|c|c|c|c|c|c|c|}
\hline \multirow{4}{*}{3} & \multirow{4}{*}{ Slope $\left[{ }^{\circ}\right]$} & $\begin{array}{l}\text { flat } \\
(0-3)\end{array}$ & very high & 1 & 1 & 62.5 & 62 \\
\hline & & $\begin{array}{l}\text { gentle } \\
\text { slope } \\
(3-6)\end{array}$ & moderate & $1 / 3$ & 0.3 & 18.75 & 19 \\
\hline & & $\begin{array}{c}\text { moderate } \\
\text { slope } \\
(6-12)\end{array}$ & low & $1 / 5$ & 0.2 & 12.5 & 12 \\
\hline & & $\begin{array}{c}\text { steep } \\
\text { slope } \\
(12-18)\end{array}$ & very low & $1 / 7$ & 0.1 & 6.25 & 7 \\
\hline \multicolumn{8}{|c|}{ Sum $=1.67$} \\
\hline \multirow{5}{*}{4} & \multirow{5}{*}{$\begin{array}{c}\text { Rainfall } \\
{[\mathrm{mm}]}\end{array}$} & 229-233 & very high & 1 & 1 & 56.17 & 56 \\
\hline & & $226-229$ & high & $1 / 3$ & 0.33 & 16.85 & 17 \\
\hline & & $222-226$ & moderate & $1 / 5$ & 0.2 & 11.23 & 11 \\
\hline & & 219-222 & low & $1 / 7$ & 0.14 & 7.86 & 8 \\
\hline & & 216-219 & very low & $1 / 9$ & 0.11 & 6.17 & 6 \\
\hline
\end{tabular}

\section{Results and Discussions}

\subsection{Drainage Density}

Drainage density is an important parameter in assessing the distribution of the groundwater potential of an area [6,11,25]. It is defined as the spatial distribution of the total length of all drainage channels per unit area [9]. The drainage density and surface runoff are directly correlated to each other. Compared to those regions having high drainage density, a low drainage density implies more infiltration [29] and good sources of high GWPS [1]. In this study, drainage density was extracted from SRTM DEM images using the natural break method [30]. The drainage density map has been classified into three classes marked as low $\left(<0.6 \mathrm{~km}^{2}\right)$, medium $\left(0.6-1.8 \mathrm{~km}^{2}\right)$ and high $\left(>3.2 \mathrm{~km}^{2}\right)$, as shown in Figure 4 a. High weightage was assigned to those regions that occupied low drainage density as compared to high drainage density zones. Therefore, the zones having low to moderate drainage density $\left(<0.6-1.8 \mathrm{~km}^{2}\right)$ have been considered best for high groundwater recharge identification (Tab. 2). 


\subsection{Elevation}

Elevation refers to the height of an area concerning mean sea level. It is a favorable parameter allowing groundwater infiltration into subsurface recharge $[3,10]$. Water is more permeable at a lower topography than higher [11, 12]. The elevation map of the study area was prepared from the ASTER DEM image, which ranges from 1369 to $208 \mathrm{~m}$ above mean sea level. The area has been classified as very high (1669-663 m), high (663-493 m), moderate (493-385 m), low (385-200 m) and very low (313-208 m), as shown in Figure 4b. High weightages were assigned to low elevated areas (i.e. low and very low), have more resistance for groundwater, while low weightages were assigned to high elevated regions, as shown in Table 2.

\subsection{Slope}

Slope is one of the significant parameters playing an important role in water infiltration and runoff [19]. Slope is inversely proportional to infiltration, so the gentler the slope, the higher the surface runoff would be, leading to low infiltration and vice versa $[3,10]$. The slope map of the study area was derived from STRM DEM images and has been classified into four classes, namely, flat slope $\left(0-3^{\circ}\right)$, gentle slope $\left(3-6^{\circ}\right)$, moderate slope $\left(6-12^{\circ}\right)$, steep slope $\left(12-18^{\circ}\right)$, as shown in Figure 4c. The areas with flat slope $\left(0-3^{\circ}\right)$ are considered "very good" for groundwater recharge potential and it occupies most of the study area. The areas with a gentle slope $\left(3-6^{\circ}\right)$ and moderate slope $\left(6-12^{\circ}\right)$ are considered as moderate recharge sites while steep slope (above 18 degrees) are considered "bad" for groundwater recharge potential due to their high slopes. Weightages to each class have been assigned based on their respective influence of groundwater occurrence, infiltration and recharge (Tab. 2).

\subsection{Rainfall}

Rainfall is the major component of the hydrological cycle and a primary water input source for surface hydrology [11]. The amount of rainfall is not constant everywhere due to climatic variations within a region [9]. The district is dependent on the monsoonal rainfall which is received from both the southwest and northeast monsoon [17]. The annual average rainfall in the study area for the last 10 years ranges from 216 to $233 \mathrm{~mm}$. The rainfall map has been derived using the Inverse Distance Weighted (IDW) interpolation technique of the rainfall data on available rain gauge stations. The derived map was acquired and categorized into five classes as shown in Figure $4 \mathrm{~d}$. Based on the analysis in this study, it was observed that the central and south-western parts of the study area received more rainfall $(233 \mathrm{~mm})$, therefore, a high weightage of 0.33 was assigned. The northern part received low rainfall $(216 \mathrm{~mm})$, as a result low weightage of 0.11 was given accordingly (Tab. 2). 

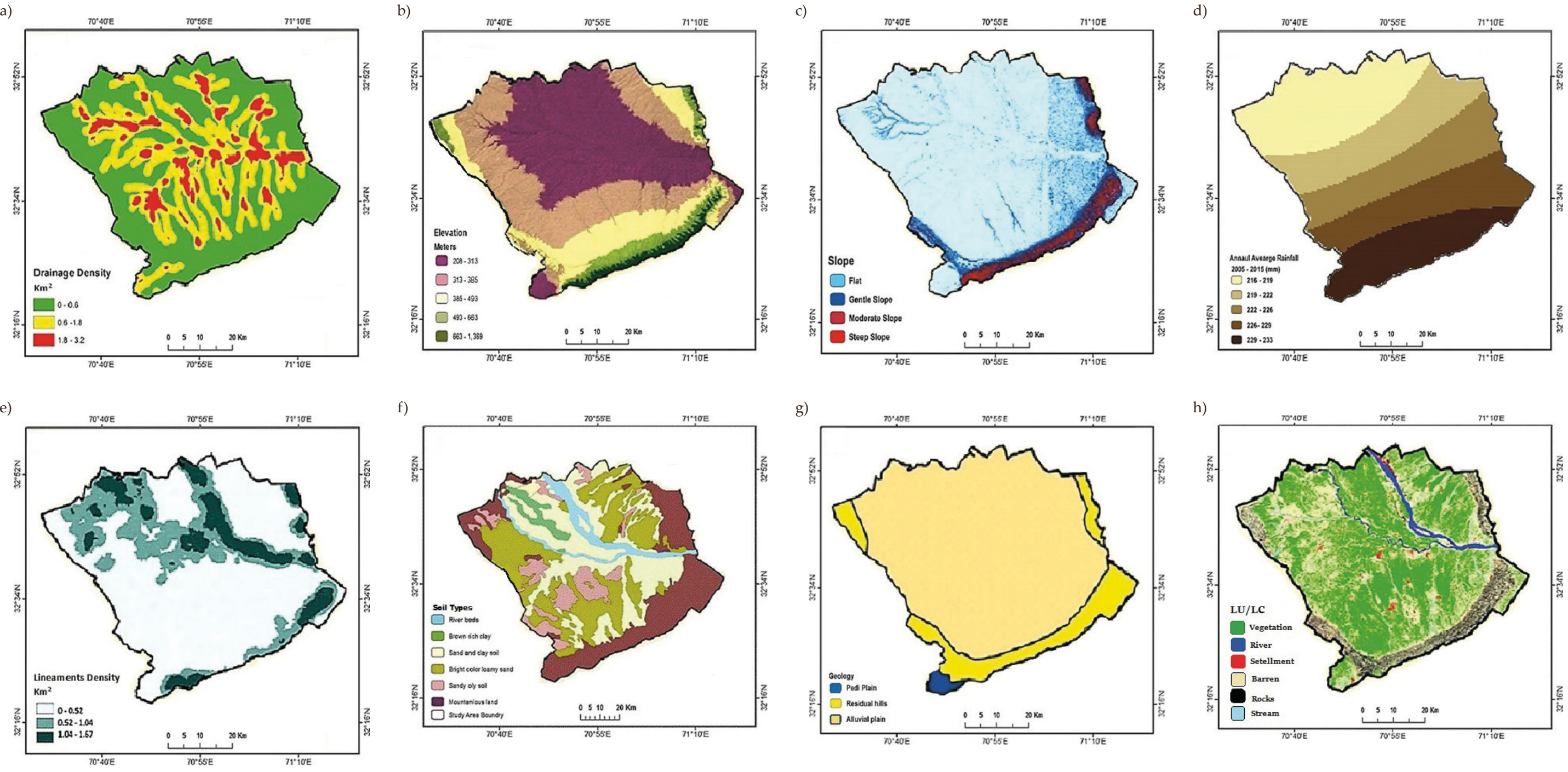

Fig. 4. Different thematic layers: a) drainage density; b) elevation; c) slope; d) rainfall; e) lineament density; f) soil; g) geology; h) LU/LC 


\subsection{Lineament Density}

Lineaments are linear or curvilinear structures of geological significance extended over several kilometers [12]. These features give insightful information about faults and fractures (crack) zones [9, 23]. Since the presence of lineaments usually signifies permeable sites, lineament in an area can represent ultimate groundwater sources. Similarly, the higher the lineament density, the richer the groundwater potential would be $[8,11]$. Lineaments of the study area were generated from Landsat- 8 panchromatic reflected band. The region was classified into three classes, i.e. low $\left(<0.52 \mathrm{~km}^{2}\right)$, medium $\left(0.52-1.04 \mathrm{~km}^{2}\right)$ and high $\left(>1.67 \mathrm{~km}^{2}\right)$, as shown in Figure 4e. The zones with the highest lineament density $\left(>1.67 \mathrm{~km}^{2}\right)$ represent the higher permeability and porosity of the soil, hence weights were assigned based on infiltration and recharge properties of lineaments (Tab. 2).

\subsection{Soil}

The hydraulic characteristics of soil play a significant role in the underground movement of surface water reaching the water table [21]. The nature of soil determines the movement of groundwater and its infiltration [11]. Therefore, the study of soil is an important factor in determining the extent of water recharge potential [20,23]. The soil distribution map was digitized from the topographic sheet and categorized into six main classes, namely: river beds, brown rich clay, sand and clay soil, loamy sand, sand and silt, gravelly and sandy land, mountainous land, shown in Figure 4f. The central part of the district consists of river beds along with clay and sandy deposits. Silt and loamy soil are located at low elevated areas situated in the southern and western parts. Brown rich clay and sand and clay soil deposits are mainly located in the central part of the district while the mountainous land (Pezu Range) is situated in the surrounding parts of the study area. Based on their hydraulic properties, brown rich clay and sand and clay soil deposits were assigned a high weightage due to their high recharge capacity with respect to groundwater infiltration capacity. The weights were assigned based on the water-logging and holding characteristics of soil types (Tab. 2).

\subsection{Geology}

Geological structures play an important role in controlling the quality and quantity of groundwater in an area [21, 23]. It helps to understand the structural importance, physiography and different landforms in the study area with respect to water infiltration capacity [5]. The geological map was acquired from NCEG, University of Peshawar [14]. According to the geological records, the Lakki Marwat district is characterized by three types of geological features: alluvial plain, pedi plain and residual hills, as shown in Figure 4g. The residual hills and shallow weathered pedi plain have poor permeability to hold water due to their high sloping topography. The alluvial plain has a high porosity due to clay and sandy texture which acts as an aquifer system. Weights were assigned to each class as per the surface influence and recharge properties (Tab. 2). 


\subsection{Land Use and Land Cover (LU/LC)}

Land use indicates how humans utilize the landscape, while land cover represents how much land is covered by physical features $[2,5]$. The LU/LC map of the study area was derived from Landsat- 8 imagery using the supervised image classification technique. The derived results of the study exhibit six classes including vegetation, settlements, river, barren land, streams and hills, as shown in Figure $4 \mathrm{~h}$. The image classification of the study area shows scattered vegetation cover. The settlements were spread over the district, particularly near water bodies. The settlement pattern is nucleated, as such type of pattern is found mainly in desert regions. Vegetation and water bodies represent very high and high classes concerning demarcated sources of groundwater potential. The settlements and barren lands represent moderate and low classes contributing to infiltration as compared to surface runoff. The weight is assigned based on the water-logging and runoff properties of LU/LC (Tab. 2).

\subsection{Weighted Overlay Analysis and Delineation of Groundwater Potential Sites}

The delineated GWPS map was derived after integrating eight contributing parameters for groundwater potential recharge over an area. Weights were assigned to each parameter and reclassified according to its influence followed by a weighted overlay operation (Tab. 3). The result of overlay analysis has been classified based on the availability of groundwater into five classes as very high (80-120 ft), high (137-180 ft), moderate (290-412 ft), low (434-590 ft) and very low (629-800 ft), as shown in Figure 6.

Table 3. Percentage of influencing factors based on Saaty's AHP

\begin{tabular}{|c|c|c|c|c|c|c|}
\hline $\begin{array}{c}\text { Serial } \\
\text { no. }\end{array}$ & Influencing factor & Scale & $\begin{array}{c}\text { Saaty's } \\
\text { scale } \\
\text { [fraction] }\end{array}$ & $\begin{array}{c}\text { Saaty's scale } \\
\text { [decimal] }\end{array}$ & $\begin{array}{c}\% \text { influence }=(\text { Saaty's } \\
\text { scale } / \text { sum }) 100\end{array}$ & $\begin{array}{c}\text { Relative } \\
\text { influence } \\
\text { value }\end{array}$ \\
\hline 1 & Geology & \multirow{8}{*}{ High } & 1 & 1 & 35.58 & 35 \\
\hline 2 & Lineament density & & $1 / 2$ & 0.5 & 17.85 & 18 \\
\hline 3 & Drainage density & & $1 / 3$ & 0.33 & 11.74 & 12 \\
\hline 4 & Soil & & $1 / 4$ & 0.25 & 8.9 & 9 \\
\hline 5 & Slope & & $1 / 5$ & 0.2 & 7.11 & 7 \\
\hline 6 & Rainfall & & $1 / 6$ & 0.16 & 5.71 & 6 \\
\hline 7 & $\mathrm{LU} / \mathrm{LC}$ & & $1 / 7$ & 0.14 & 5.10 & 5 \\
\hline 8 & Elevation & & $1 / 8$ & 0.12 & 4.46 & 4 \\
\hline
\end{tabular}


From the classification result, it was found that out of total 3,164 $\mathrm{km}^{2}$ area, $516 \mathrm{~km}^{2}$ area represents very high-class groundwater, $764 \mathrm{~km}^{2}$ represents high class, $1,137 \mathrm{~km}^{2}$ represents moderate class, $482 \mathrm{~km}^{2}$ area represents low class and $262 \mathrm{~km}^{2}$ area represents a very low class (Tab. 4). The study concluded that the central region of the district has higher potential for groundwater availability. The very high and high GWPS contain soil units of river beds, sandy and clay soil and brown rich clay, geological quaternary sediments of alluvial plain, high lineaments density, low elevation, moderate drainage density and rainfall. The moderate potential zone is dominated by soil units of loamy soil and sandy oily soil, alluvial plain and adequate residual hills, moderate to low lineaments density, moderate to low rainfall at the southern side and moderate to high at the northern, moderate elevation and moderate to low drainage density. The low and very low potential zones are present mainly in the surrounding region of the study area, having residual hills, high elevation, sandy soil texture, low drainage density and piedmont regions (Section 3).

Table 4. Groundwater potential zones of the study area

\begin{tabular}{|c|c|c|c|c||}
\hline $\begin{array}{c}\text { Serial } \\
\text { no. }\end{array}$ & $\begin{array}{c}\text { Groundwater potential } \\
\text { zones }\end{array}$ & Area [km²] & Area [\%] & Depth range [ft] \\
\hline \hline 1 & very high & 516 & 17 & $80-120$ \\
\hline 2 & high & 764 & 24 & $130-180$ \\
\hline 3 & moderate & 1,137 & 36 & $290-412$ \\
\hline 4 & low & 262 & 15 & $434-590$ \\
\hline 5 & very low & 8 & $629-800$ \\
\hline
\end{tabular}

\subsection{Ground Verification of the Modelled Results}

For the verification of the resultant map (the modeled result derived from the weighted overlay analysis), secondary field data from tube wells (acquired from GLIO) were used. The obtained field data (existing 14 tube wells) were plotted based on their latitude/longitude location in a GIS environment. The interpolation result shows the spatial distribution of groundwater depth which ranges from 70 to $799 \mathrm{ft}$ (Fig. 5). Similar to the weighted overlay analysis, the plotted sample data of tube wells also demarcate that the central part of the study area has high potential for freshwater availability due to its flat terrain while surrounding areas have a low potential for groundwater due to their mountainous topography and sandy soil texture. Furthermore, groundwater table contours were generated from the interpolated tube well data and overlaid with the model output map from weighted 
overlay analysis (Fig. 6). The existing groundwater table corresponds very well to the derived modeled map. Furthermore, it was found that half of the field samples (7 out of 14) were located in the region where a high groundwater potential zone exists for freshwater (Figs. 5, 6).

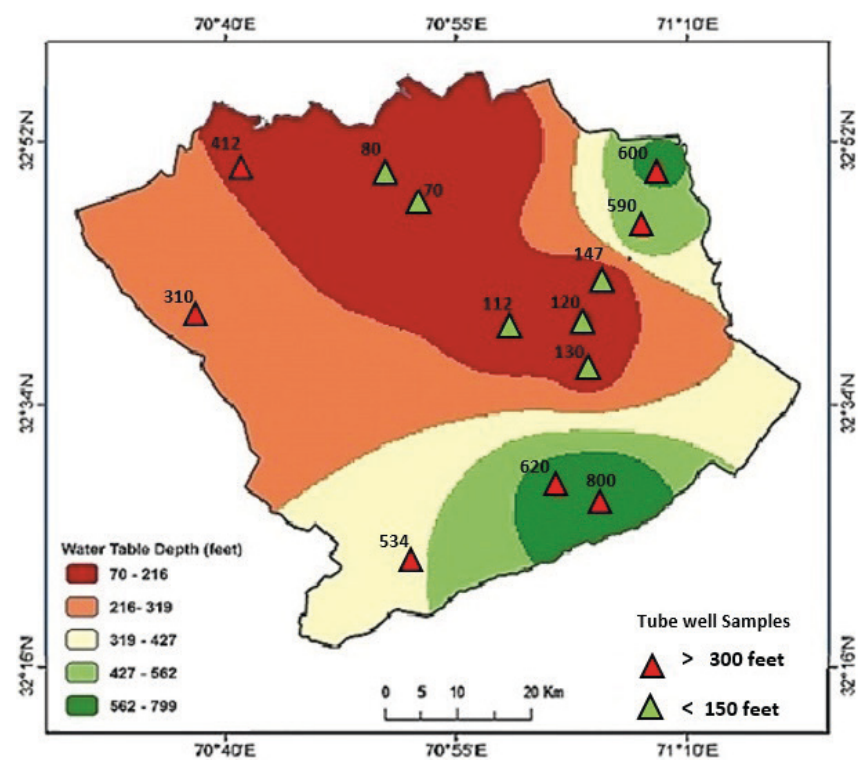

Fig. 5. Tube well observation data showing water table depth of the study area

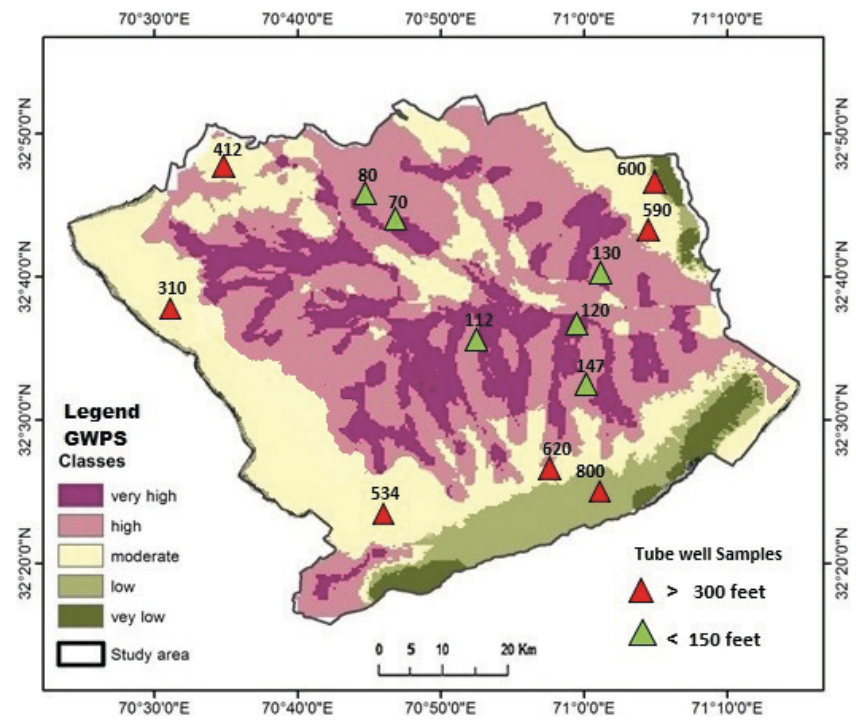

Fig. 6. Validation of field sample data with final model results 
The main part of Pakistan has semi-arid to arid conditions with limited groundwater resources. To cope with the groundwater depletion crises, climate change threats and its impacts, groundwater resources need to be monitored frequently with new state-of-the-art techniques. In this regard, the current study is a good contribution to managing water resources in a semi-arid environment with limited in situ data availability, even though conventional approaches, such as drilling, hydrogeological, geological, field surveys, and geophysical methods, are more precise. However, these methods are costly, time consuming, and labor-extensive. Therefore, the GIS-based systematic approach of integrating remotely sensed (Landsat- 8 \& SRTM) and data from other secondary sources with the modelled AHP technique adopted in this study will improve the sustainable use of groundwater resources and its mapping in semi-arid regions.

\section{Conclusion}

The present study demonstrates the application of GIS and remote sensing for determining GWPS in a semi-arid environment. In this study, remote sensing data in a GIS environment provided more accurate and reliable spatial results to evaluate the spatio-temporal dynamics of groundwater as compared to conventional techniques. For this purpose, the applicability of Saaty's AHP approach was proved to be an appropriate method for studying groundwater potentials in a semi-arid environment.

The following conclusions were derived:

- The major part of the study area, $23 \%$, exhibits poor recharge potential in the category of low (15\%) and very low $(8 \%)$.

- The area with the best recharge potential is $41 \%$, located in the central plains of the study area, having classes rated as high (17\%) and very high $(24 \%)$.

- The central plains with good recharge potential are mainly composed of Quaternary alluvial deposits with vegetation cover.

- Drainage density was found to be the most suitable parameter for identifying the recharge potential in the study area.

- The integration of the AHP approach with remote sensing data in a GIS environment was proven to be a cost and time-effective technique for surface and sub-surface water management.

- The current study could assist hydrologists in locating sites for artificial recharge structures and wells/tube wells.

- The outcome of this study may help the authorities plan the sustainable exploitation of groundwater resources in the southern semi-arid parts of the region.

- The concentration of the Kurram River drainage and its tributaries increases the recharge potential of the groundwater system.

- Low recharge potential sites are located in mountains, ridges and residual hills with steeper/gentle slopes where high run-off and underlying rock structure reduces the infiltration capability. 
Furthermore, to assure the long-term sustainability of this vital and significant natural resource, the methodology adopted in this study would be helpful in formulating an effective groundwater investigation mechanism, especially in arid and semi-arid environments. The robustness of this approach may be tested in an area with no or fewer tube wells.

\section{References}

[1] Srivastava P.K., Bhattacharya A.K.: Groundwater assessment through an integrated approach using remote sensing, GIS and resistivity techniques: a case study from a hard rock terrain. International Journal of Remote Sensing, vol. 27, no. 20, 2006, pp. 4599-4620. https://doi.org/10.1080/01431160600554983.

[2] Al-Djazouli M.O., Elmorabiti K., Rahimi A., Amellah O., Fadil O.A.M.: Delineating of groundwater potential zones based on remote sensing, GIS and analytical hierarchical process: a case of Waddai, eastern Chad. GeoJournal, vol. 86, 2021, pp. 1881-1894. https://doi.org/10.1007/s10708-020-10160-0.

[3] Singh P., Singh A., Vijhani A.: Groundwater potential zone mapping approach in Chandraprabha Basin UP using remote sensing \& GIS Technology. [in:] 15th Esri India User Conference, Delhi, 2014, UCP0031. https://www.esri.in/ /media/ esri-india/files/pdfs/events/uc2014/proceedings/papers/UCP0031.pdf?la=en.

[4] Hashemi H., Uvo C.B., Berndtsson R.: Coupled modeling approach to assess climate change impacts on groundwater recharge and adaptation in arid areas. Hydrology \& Earth System Sciences, vol. 19, no. 10, 2015, pp. 4165-4181. https://doi.org/10.5194/hess-19-4165-2015.

[5] Aneesh R., Deka P.C.: Groundwater potential recharge zonation of Bengaluru urban district - a GIS based analytic hierarchy process (AHP) technique approach. International Advanced Research Journal in Science, Engineering and Technology, vol. 2, no. 6, 2015, pp. 129-136.

[6] Harinarayana P., Gopalakrishna G., Balasubramanian A.: Remote sensing data for groundwater development and management in Keralapura watersheds of Cauvery basin, Karnataka, India. The Indian Mineralogist, vol. 34, no. 2, 2000, pp. 11-17.

[7] Kahlown M.A., Majeed A.: Water-resources situation in Pakistan: challenges and future strategies. [in:] Water Resources in the South: present scenario and future prospects, COMSATS, 2003, pp. 21-39.

[8] Abdullah A., Akhir J.M., Abdullah I.: Automatic mapping of lineaments using shaded relief images derived from digital elevation model (DEMs) in the Maran-Sungi Lembing area, Malaysia. Electronic Journal of Geotechnical Engineering, vol. 16, no. 6, 2010, pp. 949-958.

[9] Adiat K., Nawawi M., Abdullah K.: Assessing the accuracy of GIS-based elementary multi criteria decision analysis as a spatial prediction tool - a case of predicting potential zones of sustainable groundwater resources. Journal of Hydrology, vol. 440-441, 2012, pp. 75-89. https://doi.org/10.1016/j.jhydrol.2012.03.028. 
[10] Jha M.K., Chowdary V., Chowdhury A.: Groundwater assessment in Salboni Block, West Bengal (India) using remote sensing, geographical information system and multi-criteria decision analysis techniques. Hydrogeology Journal, vol. 18, no. 7, 2010, pp. 1713-1728. https://doi.org/10.1007/s10040-010-0631-z.

[11] Saranya T., Saravanan S.: Groundwater potential zone mapping using analytical hierarchy process (AHP) and GIS for Kancheepuram District, Tamilnadu, India. Modeling Earth Systems and Environment, vol. 6, 2020, pp. 1105-1122. https://doi.org/10.1007/s40808-020-00744-7.

[12] Chowdhury A., Jha M.K., Chowdary V.: Delineation of groundwater recharge zones and identification of artificial recharge sites in West Medinipur district, West Bengal, using RS, GIS and MCDM techniques. Environmental Earth Sciences, vol. 59, no. 6, 2010, 1209. https://doi.org/10.1007/s12665-009-0110-9.

[13] Majeed Z., Piracha A.: Water conservation of Pakistan's agricultural, municipal and industrial water. International Journal of Water Resources and Arid Environments, vol. 1, no. 3, 2011, pp. 232-238. https://doi.org/10.1007/s10661014-3876-5.

[14] Farid A., Khalid P., Jadoon K.Z., Jouini M.S.: The depositional setting of the Late Quaternary sedimentary fill in southern Bannu basin, Northwest Himalayan fold and thrust belt, Pakistan. Environmental Monitoring and Assessment, vol. 186, no. 10, 2014, pp. 6587-6604. https://doi.org/10.1007/s10661-014-3876-5.

[15] UNESCO: Water in a Changing World (WWDR-3): the 3rd United Nations World Water Development Report. UNESCO World Water Assessment Programme, 2009, http://www.unesco.org/new/en/natural-sciences/environment/water/ wwap/wwdr/wwdr3-2009/ [access: 7.06.2019].

[16] Ahmad N., Khan M.R.: Evaluation of a distinct sub-play for enhanced exploration in an emerging petroleum province, Bannu-Kohat sub-basin, Pakistan. [in:] AAPG International Conference and Exhibition, Milan, Italy, October 23-26, 2011. https:// www.searchanddiscovery.com/documents/2012/10391ahmad/ndx_ahmad.

[17] Ullah S., Khan M.R., Shah N.A., Shah S.A., Majid M., Farooq M.A.: Ethnomedicinal plant use value in the Lakki Marwat District of Pakistan. Journal of ethnopharmacology, vol. 158, 2014, pp. 412-422. https://doi.org/10.1016/ j.jep.2014.09.048.

[18] Saeed T.U., Khan D.: Assessment and conservation of groundwater quality: A challenge for agriculture. British Journal of Applied Science \& Technology, vol. 4, no. 8, 2014, pp. 1256-1272. https://doi.org/10.9734/BJAST/2014/6353.

[19] Tweed S.O., Leblanc M., Webb J.A., Lubczynski M.W.: Remote sensing and GIS for mapping groundwater recharge and discharge areas in salinity prone catchments, southeastern Australia. Hydrogeology Journal, vol. 15, no. 1, 2007, pp. 75-96. https://doi.org/10.1007/s10040-006-0129-x.

[20] Singh K.P., Basant A., Malik A., Jain G.: Artificial neural network modeling of the river water quality - a case study. Ecological Modelling, vol. 220, no. 6, 2009, pp. 888-895. https://doi.org/10.1016/j.ecolmodel.2009.01.004. 
[21] Yeh H.F., Lee C.H., Hsu, K.C., Chang P.H.: GIS for the assessment of the groundwater recharge potential zone. Environmental Geology, vol. 5, no. 1, 2009, pp. 185-195. https://doi.org/10.1007/s00254-008-1504-9.

[22] Shekhar S., Pandey A.C.: Delineation of groundwater potential zone in hard rock terrain of India using remote sensing, geographical information system (GIS) and analytic hierarchy process (AHP) techniques. Geocarto International, vol. 30, no. 4, 2015, pp. 402-421. https://doi.org/10.1080/10106049.2014.894584.

[23] Pinto D., Shrestha S., Babel M.S., Ninsawat S.: Delineation of groundwater potential zones in the Comoro watershed, Timor Leste using GIS, remote sensing and analytic hierarchy process (AHP) technique. Applied Water Science, vol. 7, no. 1, 2017, pp. 503-519. https://doi.org/10.1007/s13201-015-0270-6.

[24] Sujatha E.R., Sridhar V.: Landslide susceptibility analysis: a logistic regression model case study in Coonoor, India. Hydrology, vol. 8, no. 1, 2021, 41. https:// doi.org/10.3390/hydrology8010041.

[25] Arshad A., Zhang Z., Zhang W., Dilawar A.: Mapping favorable groundwater potential recharge zones using a GIS-based analytical hierarchical process and probability frequency ratio model: A case study from an agro-urban region of Pakistan. Geoscience Frontiers, vol. 11, no. 5, 2020, pp. 1805-1819. https://doi.org/ 10.1016/j.gsf.2019.12.013.

[26] Baker C., Lawrence R., Montagne C., Patten D.: Mapping wetlands and riparian areas using Landsat ETM+ imagery and decision-tree-based models. Wetlands, vol. 26, no. 2, 2006, pp. 465-474. https://doi.org/10.1672/0277-5212(2006)26 [465:MWARAU]2.0.CO;2.

[27] Saaty T.L.: How to make a decision: the analytic hierarchy process. European Journal of Operational Research, vol. 48, no. 1, 1990, pp. 9-26. https://doi.org/ 10.1016/0377-2217(90)90057-I.

[28] Mukul M., Srivastava V., Jade S., Mukul M.: Uncertainties in the shuttle radar topography mission (SRTM) Heights: Insights from the Indian Himalaya and Peninsula. Scientific Reports, vol. 7, no. 1, 2017, 41672. https://doi.org/10.1038/ srep41672.

[29] Magesh N.S., Chandrasekar N., Soundranayagam J.P.: Delineation of groundwater potential zones in Theni district, Tamil Nadu, using remote sensing, GIS and MIF techniques. Geoscience Frontiers, vol. 3, no. 2, 2012, pp. 189-196. https:// doi.org/10.1016/j.gsf.2011.10.007.

[30] Jenks G.F.: The data model concept in statistical mapping. [in:] Frenzel K. (ed.), International Yearbook of Cartography, vol. 7, George Philip, 1967, pp. 186-190. 